\title{
correspondence
}

\section{Soviet genetics}

SIR,-Dr Italo Barrai in his letter (Nature 271, 8; 1978) commenting on my earlier article on the new controversy on human genetics in the USSR (Nature 268, 285; 1977) asks me two questions which I shall answer here.

Barrai questions my ability to describe the situation in genetics “. . . what can a gerontologist say about human genetics : in what position is he to pass value judgement?"

It is true that most of my research while in the USSR and here in UK had been related to problems of ageing. However, my book The Rise and Fall of T.D. Lysenko, published by Columbia University Press in 1969 is still the only book written and published by a Russian scientist about the history of genetic controversy in the Soviet Union. This book also described the history of medical genetics in the USSR from 1920 to 1967. My article in Nature was in some way a continuation of these accounts.

Barrai's second question asks that I prove that in $1976 \mathrm{~N}$. V. Tsitsin was not yet appointed president of the Genetic Congress (which takes place in Moscow in August 1978). The proof comes in the decision about the Moscow Congress made at the previous Congress in Berkeley in 1973. At this Congress D. K. Beliaev, in his capacity of the President of the Soviet Genetic Society, made an invitation on behalf of the Government of the USSR, to hold the next Congress in Moscow. As soon as the invitation was accepted D. K. Beliaev started to make all necessary arrangements as acting President. N. V. Tsitsin's name as president of the Congress appeared only in 1977, and I believe that it surprised not only me, but also the International Genetic Federation. N. V. Tsitsin, now 80 years old, was never very popular among geneticists, mostly because the way in which he acquired prominence in the mid-1930s. One can read about this in the book by Prof. D. Joravsky The Lysenko Affair (Harvard University Press : Boston, 1970)-

"In 1932 Tsitsin moved to the West Siberian Experimental Station in Omsk, whose director, V. R. Berg, believed in the practicality of crossing wheat with couch grass. He had been working on the problem himself.

"A year after Tsitsin's arrival in Omsk, Berg was arrested as a 'wrecker', and Tsitsin was made a hero by the mass media, even though (or because) he still complained that 'an enormous portion of specialists up to the present are extremely negatively inclined toward our work.' A commission of inquiry from the Commissariat of Agriculture, which was itself being purged of 'wreckers', decided that Tsitsin's work had enormous promise and merited great support. He was given space in Pravda to promise an annual hybrid of wheat and couch grass ready for production testing by the fall of 1935; a perennial would take a year longer. When 1935 came to an end without a hybrid ready for the testing service, Tsitsin received reassurance from the highest authority. Stalin told him, and allowed the awesome words to be inscribed on newsprint: 'Experiment more boldly. We will support you'. Tsitsin became the director of the Omsk station, which had been promoted into the Siberian Institute of Grain Culture. Specialists began to pay respectful attention to his work."

Everything in this description is correct. One can find details of the events in Pravda for 9 July 1934 and 30 December 1935, pp. 81-82. N. V. Tsitsin has still not made perennial wheat, but as a director of a big plant breeding research institute after the second world war he could be given credit for some achievements in wheat breeding. He has not played any serious role in Soviet genetics for the last five years; and his name was removed from the editorial board of the Soviet journal Genetica at the very beginning of 1973 . If Soviet geneticists had had a free choice of who was to be president of the first International Congress on Genetics held in the USSR I doubt very much that Tsitsin would have got the job.

Dr Barrai also asked me to give a fuller justification of my negative assessment of N. P. Dubinin's current work. I am afraid that this needs more space than this letter permits. Dr Barrai, however, partly provided the answer himself. Trying to explain some false methods in N. P. Dubinin's publications Dr Barrai wrote “. . . it might well be that, as director, he signs work from his institute which might be beyond the capacity of his technical judgement". Some of my colleagues in the USSR also thought that this could be the case. They thought, however, that this could equally be said about publications which were not failures. In any case the Moscow Congress will provide enough information about the situation in Soviet genetics today for those who do not restrict their interest to the official programme. Yours faithfully, Zhores A. Medvedev

National Institute for Medical Research, London

\section{NIH guideline ineffective}

SiR,- The National Institute of Health Guidelines for Recombinant DNA Research recommended $2 \%$ aqueous Wescodyne, an iodophore that is used in many hospitals and laboratories as a disinfectant, as a decontaminant for biological safety cabinets and $5 \%$ for a spill outside a cabinet. A contact time of 10 to 15 minutes was given for the $2 \%$ solution and 20 minutes was considered adequate for the $5 \%$ concentration.

However I have conducted experiments which indicate :

- Aqueous Wescodyne $(5 \%)$ is ineffective when used for 80 minutes against poliovirus in a test mixture containing $8.5 \%$ bovine serum albumin (a mixture equivalent in protein concentration to the higher range in serum).

- Wescodyne $(10 \%)$ employed under the same conditions for 40 minutes is also ineffective.

- Wescodyne $(10 \% \mathrm{v} / \mathrm{v})$ in $50 \%$ ethanol (w/w) was effective and this mixture, originally recommended for hand washing, should be considered for use in biohazard situations, particularly for decontamination of work surfaces and biological safety cabinets.

These results are significant, for if a virucide cannot inactivate poliovirus one would be concerned about using the virucide against hepatitis $B$ or SV40 viruses. Yours faithfully, Alfred M. Wallbank The University of Manitoba, Winnipeg, Canada 